SEFAD, 2018 (40): 1-22

e-ISSN: 2458-908X

DOI Number: https://dx.doi.org/10.21497/sefad.514442

\title{
Yirminci ve Yirmi Birinci Yüzyıl Gezi Edebiyatında Ev/Yurt Algısı*
}

\author{
Dr. Abdulfettah Imamoğlu \\ Eskişehir Osmangazi Üniversitesi Fen Edebiyat Fakültesi \\ Karşılaştırmalı Edebiyat Bölümü \\ aimamoglu@ogu.edu.tr
}

Öz

Yeni Eleştiri ${ }^{1}$ kuramının, eserlerin bağımsız birer yapı olduğu ve kendi kendine yeterliliği prensibinden hareketle, bu makale, konusunun şekillenmesi için referans olarak seçilen gezi edebiyatı metinlerinin sunduğu tanımlamalar ve betimlemelere olabildiğince sadık kalarak, insan yaşamı için merkezî bir mekân olma niteliğine sahip ve bununla birlikte kimlik, kültür ve kişilik gibi olgularla da bağlantılı olan ve bunun yanı sıra teknik ve teknolojik sahada kaydedilen ilerlemelerin bir sonucu olarak mekânlararası etkileşimin daha sık ve daha hızlı gerçekleştiği son iki yüzyılın kayda değer sorunsallarından olan ev ve yurt algısına dair bir inceleme sunmayı hedefliyor. Bu bağlamda, referans olarak seçilen metinler, yalnızca deneyimsel nitelikleriyle değil aynı zamanda "gezi edebiyatı teorisi eseri" nitelikleriyle bağlantılı olarak da ele alınacaktır. Dolayısıyla, algılayıcı özne olarak insan ve algınanan nesne olarak mekân diyalektiğinden hareketle, gezgin-yazar olarak nitelendirilebilecek çağdaş yazarlar tarafından, evlerinden ve yurtlarından, alışılmış ve sıradan olandan uzakta, dünyanın çeşitli yerlerinde gerçekleştirilen gezi deneyimlerinin edebî boyut kazanmış hâli olan gezi edebiyatı eserleri, içerdikleri parçalar aracılığıyla, bu makalenin konusu olan mekân algısı paradigmasına yaklaşımda izlenecek tutumu birincil elden besleyeceklerdir. Böylelikle, belirli bir mekânsal gerçekliği yansıtan kavramlar olan ev ve yurdun gezgin-yazar açısından algısı noktasında, biri diğerinden bağımsız şartlarda gerçekleşmiş olsa dahi birbirini besleyen ya da tamamlayan bireysel deneyimler neticesinde yazıya aktarılan tanımlama ve yaklaşımlar üzerinden mekân algısı meselesinin farklı boyutları göz önüne serilecek, bu sayede de mekân olgusuna dair önerilecek olan herhangi bir yargının hem bütünselliğine hem de eksikliğine vurgu yapılmış olacaktır.

Anahtar Kelimeler: Ev, başka-yer, öz-yer, gezi edebiyatı.

\footnotetext{
* Bu makale, Prof. Dr. Eric Dayre danışmanlığında tamamlanan La notion d'Ailleurs dans les récits romanesques du XXe et du XXIe siècles (Yirminci ve Yirmi Birinci Yüzyıl Romanesk Yazınında Ailleurs Kavramı) başlıklı Doktora tezinden üretilmiştir.

1 Yeni Eleştiri (New Criticism), bir eserin kaynak veya kaynaklarına ve sosyokültürel arka planına odaklanmaktan ziyade, sayfalarında yer alan kelimeleri merkeze koyan, edebî eserleri, eser dışındaki ögelerden bağımsız, otonom ve organik unsurlar olarak ele alan bir eleştiri yaklaşımı, anlayışı olarak tanımlanabilir (Das 2005: 24-25).
} 


\title{
The Conception of Home in the Twentieth and Twenty-First Century Literature of Travel
}

\begin{abstract}
In relation with technical and technological progress that have made the communication between places faster and more frequent, the conception of home represents a significant issue in twentieth and twenty-first centuries. Home, a conceptual notion designating a central place for human living, refers to a symbolic place which is also related to terms like identity, culture and personality. The notion of home embodies particular conditions regarding the relation between human being as perceiver subject and place as perceived object. By choosing New Criticism as the method to approach the contemporary literary works selected for the development of this work ${ }^{2}$ after their potential quality to be part of a "travel literature theory", this paper aims to constitute a definition of place from the perspective of literary travelers who carry out considerations about the signification of place from their own personal experiences that are taken place in elsewhere, in other-place, in places situated far from home, far from the ordinary, the familiar, the known. Realized in situations and conditions being independent from each other, those experiences, through their complementary or supporting quality which is reported inside literary works in forms of definitions and approaches, will help to reveal several aspects concerning the conception of home which reflects a particular spatial reality. In this respect, the result of this work will show that all kind of judgement about a definition of home is at the same time adequate and inadequate due to complexity of conception of place.
\end{abstract}

Keywords: Home, other-place, self-place, literature of travel.

\footnotetext{
$\overline{2}$ For this article, are chosen six literary works written in three languages (French, Turkish or English) and published in different periods of twentieth and twenty-first centuries. Those works, belonging to six literatures from five continents, relate individual travel experiences realized in countries and continents different from each other, have been created by writers who represent a diversity of cultural identities. Readers can find in those works conceptual, intellectual, individual and romanesque approaches related to question of place. According to their first publication dates, those works are: Terre des hommes, Antoine de Saint-Exupéry (France, 1939); On the road, Jack Kerouac (United States of America, 1957); L'Africain du Groenland, Tété-Michel Kpomassie (Togo, 1981); Le poisson-scorpion, Nicolas Bouvier (Switzerland, 1982); Başka Yollar, Enis Batur (Turkey, 2002); Towards Another Summer, Janet Frame (New Zealand, 2007 *Post-mortem publication).
} 


\section{GİRIŞ}

On dokuzuncu yüzyılda ilk defa bağımsız bir akademik çalı̧̧ma alanı olarak ortaya çıkan ve son iki yüzyıldır kayda değer bir dinamizm sergileyen Karşılaştırmalı Edebiyat sahasının, "yabancı" kavramını ele alışı, bu kavrama atfettiği önem, edebî saha çalışmalarına yeni bir boyut kazandırıyor. Yabancı olana bakış, yabancılık deneyimi, yabancılaşma durumu gibi sorunsalları karşılaştırmalı edebiyat çerçevesinde analiz etmek, insan-mekânzaman paradigmasını farklı ve birbirini daha çok tamamlayıcı perspektiflerden ele alma olanağı tanıyor ve bu konuda daha bütünsel bir netice elde etmeye zemin hazırliyor. Yabancı kavramı ile ilgili olarak, yabancı olanı tanımlayan ve onu göreceleyen imgelere işaret eden ev/yurt kavramları, bize algınanan nesne sıfatı ile mekân ve algılayıcı özne sıfatı ile gezgin-yazar ilişkisi üzerine fikirler veriyor, birbirini tanımlayan ve tamamlayan bu iki olguya dair yeni yaklaşımlar keşfetmeyi ve geliştirmeyi mümkün kılıyor.

Çağdaş edebiyat eserlerinde yer verilen betimlemeler vasıtası ile okuyucuya sunulan ev/yurt tasviri, mekân algısında önemli bir yer tutan bu imgesel kavramları yeniden yorumluyor, onlara yeni ve farklı tanımlamalar getirmeye olanak sağlıyor. Çağdaş edebiyatın üretim açısından zengin bir kolu olan gezi edebiyatında, gezi deneyimi ile bağlantılı olarak, söz konusu algı, başka-yerde ${ }^{3}$ olmak, yabancılık durumları üzerinden bir tanıma kavuşuyor. Yurdundan/evinden geçici bir süreliğine uzaklaşan, onunla arasına bir mesafe koyan gezgin-yazar, başka-yer deneyimi süresince, zihnindeki ev/yurt imajını yeniden tanımlama, onu gözden geçirme, onu daha önce algıladığından farklı olarak, değişik bir açıdan irdeleme durumuna giriyor. Evinden uzakta, gezgin-yazar, hem zamansal hem mekânsal olarak geride bıraktığı evin/yurdun zihninde farklı formlarda belirdiğine, onda farklı hisler uyandırabildiğine şahit oluyor. Gezgin-yazarın yolculuğu esnasında bir an zihninde beliren bu ev/yurt resimleri, bize bu mekâna/mekânlara dair bir imge oluşturma imkânı tanıyor ve bu imgenin birtakım karakteristik özellikleri bize ev/yurt algısına daha objektif yaklaşma fırsatı veriyor. Söz konusu özellikler, evin/yurdun psişik, fiziksel, zamansal, bireysel ve toplumsal boyutlarını içine alacak biçimde çok yönlü bir tasvir ve analiz meydana getirmek adına temel teşkil ediyor.

Bu makale için Fransızca (Fransa Fransızcası, Togo Fransızcası, İsviçre Fransızcası), Türkçe (Türkiye Türkçesi) veya İngilizce (Amerikan İngilizcesi, Yeni Zelanda İngilizcesi) olmak üzere üç dilde kaleme alınmış ve yirminci ve yirmi birinci yüzyılın farklı dönemlerinde yayınlanmış; beş kıtada yer alan altı ülke edebiyatına ait; biri diğerinden farklı ülke ve kıtalarda gerçekleştirilmiş bireysel gezi deneyimlerini aktaran, kültürel kimlik bakımından çeşitlilik gösteren yazarlarca üretilmiş ve içerisinde mekân olgusuna dair kavramsal, düşünsel, ferdî ve romanesk yaklaşımlar barındıran altı eser seçilmiştir. Bunlar, ilk basım yılları ile beraber, şu şekildedir: Terre des hommes, Antoine de Saint-Exupéry (Fransa, 1939); On the road, Jack Kerouac (Amerika Birleşik Devletleri, 1957); L'Africain du Groenland, Tété-Michel Kpomassie (Togo, 1981); Le poisson-scorpion, Nicolas Bouvier (İsviçre, 1982); Başka Yollar, Enis Batur (Türkiye, 2002); Towards Another Summer, Janet Frame (Yeni Zelanda, $2007^{*}$ Yazarın ölümünden sonra yayınlanmıştır).

\footnotetext{
${ }^{3}$ Bu terim Fransızca ailleurs kavramına karşılık olarak yazılmıştır. Ailleurs Fransızcada "başka yer", "başka yerde", "başka bir durumda", "bir başkasında", "bir başka olgular bütününde" gibi anlamlara gelen Latince kökenli bir kelimedir. Kaynaklar: 1. CNRTL (Fransa Ulusal Metin ve Sözlük Veritabanı) Sözlüğ̈̈ (2018). 2. Dictionnaire de la Langue Française par E. Littré de l'Académie Française (1873). 3. Dictionnaire Latin-Français par Fr. Noel, Le Normant Père (1825).

* Bu makalede "başka-yer" tabiri bu tanımların bütününü içine alacak şekilde kullanılacaktır.
}

SEFAD, 2018 (40): 1-22 
Hatırlatmakta fayda var ki "Bir Ruh Hâli Olarak Ev ve Yurt", "Değişken Bir Unsur Olarak Ev ve Yurt", "Kapalı Bir Mekân Olarak Ev ve Yurt", "Yapay Bir Alan Olarak Ev ve Yurt" olmak üzere dört alt başlıkta gerçekleştirilecek tasvir ve analizler, gezi edebiyatı teorisi adına kavramsal bir perspektif elde etmek adına kısmî bir parça arz ediyor. Nitekim bu parçanın, yine bu alan üzerine eklenecek başka parçalarla desteklenmesi gerekiyor. Öyle ki, bu makale için seçilen eserler, türsel, tarihsel ya da sosyal bir sürecin parçası olmaktan ziyade, içerikleri üzerinden tek başlarına bağımsız bir yapı teşkil etmeleri noktasından hareketle bu çalışmanın kavram merkezli gelişimine katkıda bulunacaklardır. Sözü edilen katkı, her alt başlığın içeriğine en az iki referans eserin katkısı şeklinde yansıtılacak olup, bu sayı, eserlerin sunduğu tanımlamalar ve betimlemelerle doğru orantılı olarak artabilecektir. Burada esas olan, ev ve yurt algısında, aynı alt başlık altında, çeşitlilik gösteren yaklaşımlar sunmak olacaktır.

\section{Bir Ruh Hâli Olarak Ev ve Yurt}

Fransiz filozof Gaston Bachelard, evi bir état d'âme yani "ruh hâli" olarak niteler ve şöyle der: Dış mekândaki temsiline rağmen ev aslında mahremiyet demektir (1967: 77). Bachelard'ın bu nitelendirmesi hiç şüphesiz evin ve onun daha geniş çaplı bir replikası olan yurdun içinde hayatını sürdürmüş, sürdüren, sürdürecek olan insanların bu mekânla olan bağına bir göndermedir. Evde/yurtta yaşanılan hayat tecrübesi, ki bu doğumdan itibaren başlar, mekân ile sakin arasında hissel bir bağın oluşmasına zemin hazırlar. Çocukluğun geçtiği, aile bireyleriyle paylaşılan, sınırları kesin hatlarla belirlenmiş psikolojik bir mekân olarak ev, bir yaşam alanı olduğu sakinini yoğun bir mekânsal deneyimin aslî parçası hâline dönüştürür ve sakin, bu evde geçirdiği anlar ile hayatı arasında gerçekleşen deneyimin doğurduğu hislerin etkisiyle belirli bir mekân algısı edinir ve yabancı olanı bu algıdan hareketle tanımlama yoluna gider.

Peki, Bachelard örneğinden hareketle, yukarıda bahsettiğimiz bu durumu bir ruh hâli olarak tarif etmek yerinde bir tanımlama olarak varsayılabilir mi?

Çağdaş gezi edebiyatı, Bachelard'ın işaret ettiği "ruh hâli olarak ev" fikrine dair, bu psikolojik mekânı edebî ve romanesk bir çerçevede yeniden değerlendirebilmemize olanak veren içerikte eserler barındırıyor. Bu edebiyatın temsilcileri olan gezgin-yazarlar, hayatlarının ilk zamansal kesiti olan çocukluklarının geçtiği mekânı/mekânları farklı yönleriyle hatırlıyor ve bunu sözcükleriyle eserlerinde dillendiriyorlar. Bu mekân ya da mekânlardan, şimdi, bir daha dönmemek üzere, uzak olan gezgin-yazar, zihninde beliren, var olan evin/yurdun resmini okuyucuya aktarıyor. Bu resim zamansal niteliği olan bir resim olarak karşımıza çıkıyor. Artık başka-yerde olan gezgin-yazar için bu evin/yurdun işaret ettiği mekân nostaljik bir mekân izlenimi veriyor. Bu mekânı canlı tutan, yalnızca, artık bir nostaljik özne olan gezgin-yazarın zihnindeki sübjektif resim oluyor ve okuyucu, yazarın zihninde yer alan ve bütünüyle kişisel ve dış algıdan soyutlanmış bu kişisel ev/yurt resmine onun eserlerindeki betimlemelerle erişebiliyor. Gezgin-yazarın sözcükleri, geçmiş zamana has bir özelliğe sahip olan eve olgusal bir boyut katmak amaciyla okuyucunun algısına sunulan yapı malzemelerini andırıyor. Söz konusu boyut, tahmin edileceği gibi, his odaklı bir karaktere sahip olarak sağlanıyor ve bu yönüyle bir "ruh hâli" imajı veriyor.

Evinden uzakta, başka-yerde olan gezgin-yazar, yabancısı olduğu bu uzak mekânın sebep olduğu yalnızlık ve savunmasızlık etkisi altında, nostaljikleşiyor, bir nostaljik özne durumuna giriyor ve bu hâlde iken, hayatının şimdiki zamanının öncesinde var olmuş ve benliğinde yer etmiş evlerin resmi zihninde beliriyor. $\mathrm{Bu}$ resim, nostaljik özelliği ele 
alındığında, gezgin-yazar için, şüphesiz, bir özlem kaynağı olarak görülebilir. Başka-yerde bulunduğu zamanın bir kısmında, gezgin-yazarın zihnini meşgul eden bu soyut resim, ev/yurt algısına dair okuyucuya kayda değer ayrıntılar sunuyor. Bu ayrıntılar sayesinde vücut bulan ev/yurt resmi, mekân algısına dair belirli bir gezi edebiyatı teorisi önerisinde bulunmamiza olanak veriyor.

Çağdaş gezi edebiyatının önemli yapıtlarından olan ve bir yirminci yüzyıl ürünü olan On the road romanında, Amerikalı gezgin-yazar Jack Kerouac, yabancısı olduğu Harrisburg şehrinde yalnız ve dışarıda geçirdiği geceyle beraber, bize nostaljik evini şu şekilde betimliyor: "O gece, Harrisburg'ta, tren garının bir bankında yatmam gerekti; şafakla beraber, gar çalışanları beni derhal dışarı attılar. Hayatın başında, baba evinin çatısı altında her şeye inanan küçük uslu bir çocuk olduğumuz doğru değil midir? Sonrasında, o meşum felaket günü gelir ki yoksun ve sefil ve mutsuz ve kör ve çıplak olduğumuzun farkına varırız ve bir hayaleti andıran üzgün ve kasvetli bir yüzle, kâbusu andıran bir hayatın ortasından titreye titreye geçeriz." (2000: 95)

Amerika'nın Harrisburg kentinde evsizliği, yabancılığı ve yalnızlığı deneyimleyen Kerouac, bu kısa gezisi esnasında, kendini sığındığı kapalı bir alan olan tren garından dışarı atılmış bir hâlde bulmasıyla beraber, zihninde beliren ev resmini, kelimeleriyle okuyucuya aktarıyor. Bu nostaljik ev, yazarın çocukluk evresine tekabül eden bir mekânı işaret ediyor. Hayatını çocukluk ve yetişkinlik diye iki zamana ayırma eğilimine giren Amerikalı yazar, bu iki ayrı zamanı belirleyen kırılma noktasını "meşum felaket günü"4 olarak niteliyor. Buna göre, bu felaket anı, kişinin artık baba evinin koruyucu ve bir bakıma aldatıcı ortamından çıkıp dış dünyanın gerçekleriyle yüzleşmesiyle meydana geliyor. Bir başka deyişle, çocukluğunun geçtiği evin dışına çıkan, dolayısıyla yetişkinliğe adım atan Kerouac, bu yeni zaman ve mekân gerçekliğinde daha önce inandığ şeylerin bir karşılığının olmadığını görüyor ve sonuç olarak, geriye dönüş ihtimali bırakmayan bu "uyanış", çocukluğuna, çocukluğunun geçtiği mekâna nostaljik bir anlam veriyor. Yetişkin Kerouac, artık bir daha sakini olamayacağı, çocuk Kerouac'ın yaşadığı, evi özlemle anmakla, bu özel alanla şimdiki hayatı arasında bir çeşit bağ kurmuş oluyor. Kerouac'ın betimlemesi, ev kavramına romanesk bir tanım getirerek, gezi edebiyatında alan algısı bağlamında, evi hissî ve tamamıla öznel bir sınıflandırmaya sokuyor. Buna göre, başka-yer, -yalnızlık ve yabancılık gibi faktörlerin de etkisiyle, bu hissî, soyut ve bir anlık beliren mekâna açılan somut bir alan hâlini alıyor.

Kerouac gibi, nostaljik mekân algısını betimleyen bir başka gezgin-yazar olarak Fransız Antoine de Saint-Exupéry karşımıza çıkıyor. Yine bir yirminci yüzyıl ürünü olan Terre des hommes ${ }^{5}$ adlı eserinde Saint-Exupéry, uçağının arızalanması sonucu Sahra Çölü'nde mahsur kaldığı zaman içerisinde, çöldeki iklimsel koşulların ve yazarın buradaki yabancllığının sebep olduğu psikolojik durumla beraber, zihninde canlanan ev resminden bahsediyor: "Şekil değiştiren çölde, sevdiğim eski bir ev belirmişti. Bu evin yakın veya uzak olmasının, bedenimi ısıtmasının ya da beni içine almasının bir önemi yoktu. $\mathrm{O}$ ev, burada bir düştü sadece. Ancak, çölde geçirdiğim bu geceyi varlığıyla doldurması benim için önemli olan şeydi." şeklinde düşsel resmini gördüğü eski evi okuyucuya aktaran Saint-Exupéry,

\footnotetext{
${ }^{4}$ Yazar, kitabında "the day of the Laodiceans" tabirini kullanıyor. Bu tabirle, Anadolu'da milattan önce var olmuş ve güçlü bir deprem neticesinde yerle bir olmuş Laodikya (Laodikeia) kentine göndermede bulunularak "Laodikyalıların o (felaket) günü" şeklinde bir ifadede bulunuluyor.

5 "İnsanların Dünyası" olarak çevrilebilir.
}

SEFAD, 2018 (40): 1-22 
betimlemesine şöyle devam ediyor: "artık, çölde, bir kayalık üzerinde yığılmış bir beden değildim. Bu evin çocuğuydum artık. Ona canlılık veren seslerle, girişindeki o ferahlık duygusuyla, kokularının hatırasıyla doluydum." (2007: 64)

Kerouac gibi Saint-Exupéry de çocukluğunun evini nostaljik duygularla hatırlıyor ve bu geçmişte kalmış mekâna olan özlemini dillendiriyor. Ancak, Kerouac'tan farklı olarak, Fransız yazar, çocukluk evini başka-yerde geçirmekte olduğu şimdiki anını dolduran düşsel bir resim olarak görüyor ve bu resmin hayal olmasının çok da önemi olmadığını hatırlatıyor. Buna göre, bir zamanlar içindeki kokularla, seslerle bir ruh hâline işaret eden ev, artık yetişkin olan gezgin-yazar için yalnızlık, yabancılık, uzaklık hâllerinde kendisine ihtiyaç duyulan soyut bir mekâna dönüşüyor ve bu niteliğiyle bir an için yalnızlığın, yabancıllı̆ı̆ın ve uzaklığın ağırlığını hafifletmeye, onu bir an olsun unutturmaya, uzaklaştırmaya sebep oluyor. Nostaljik bir özne olarak gezgin-yazar, zihninde beliren bu resmi ev/yurt algisının bir parçası olarak bize sunuyor ve bu tarz bir betimleme, şimdi ile geçmiş, başka-yer ile ev, uzaklık ile yakınlık, yabancılık ile aşinalık, yalnızlık ile birliktelik, dış alan ile iç mekân diyalektiklerini sorguluyor, bunlara romanesk bir yorum kazandırıyor.

Zamansal niteliği ele alındığında, şimdiye dek yer verdiğimiz alıntılardan hareketle, çocukluk evinin, gezgin-yazarın yurt algısında en uzak mekân betimini temsil ettiğini görüyoruz. Burası, az önce bahsedildiği gibi, zihinde varlı̆̆ını devam ettiren soyut bir mekânı tanımlıyor. Gezgin-yazar ile bu "en uzak ev", nostaljik bir bağla anlık ve geçici olarak şimdiki zamanın bir parçası oluyor. Başka-yer, bu uzak mekânın yeniden belirmesine ortam hazırlıyor. Bir başka deyişle, başka-yerin alışılmamış mekânı, çocukluk evinin gezginyazarın hayatına etki yapmış alışılmış mekânına bir an için yer ve zaman açıyor, gezginyazarı nostaljik bir özneye çeviriyor. Peki bu nostaljik mekânı yurt olarak tanımlamak ne kadar mümkün?

Fransızca chez-soi terimi, her şeyden önce, "ikamet edilen ev" anlamına geliyor. Aynı kelime parça parça ele alındığında ise "öz", "benlik" kelimelerini niteleyen bir yerde, bir mekânda bulunmayı işaret eden bir terime karşıllk geliyor', dolayısıyla Türkçeye "öz-ev", “öz-yurt", “öz-yer", “öz-mekân” olarak çevrilebilecek bir terim vasfı gösteriyor. Başka-yerin aksine, öz-yer bir yakınlık durumunu belirtiyor ve bu vasfı ile uzaklığı tasvir eden başka-yer kavramının tam karşısında duruyor. Bu iki kavramı az ya da çok belirgin bir şekilde ayıran ise distance yani "mesafe" oluyor. Bu mesafe, kimi durumlarda alansal, kimi durumlarda zamansal bir karaktere bürünüyor.

Uzaklık ve yakınlık noktasından hareketle irdelendiğinde, nostaljik ev aynı zamanda başka-yer olma durumu gösteriyor. Zamansal mesafenin bir sonucu olarak çocukluğun geçtiği ev soyut ve hafızasal bir resme dönüşüyor ve bu resim, gezgin-yazarın çocukluk yıllarında fiziksel biçimde ve bir ruh hâli olarak var olan bu öz-yerin başkalaşmış ve başkalaşmaya devam edecek bir formu oluyor. Çocukluk evinin fiziksel olarak varlığının bugün de devam etmesi, çocukluk yılları burada geçmiş gezgin-yazarın, yetişkinlik öncesi zamanda, bu mekânda yaşadığı anların zihnindeki varlığıyla doğrudan ilişkili olduğundan ötürü, bu evin fiziksel olarak şimdiki zamanda var olması tek başına "nostaljik ev" sayılabilmesi için yeterli olmuyor. Zira bu evde bizzat gezgin-yazar tarafından yaşanan anlar ve bunların bugünkü hafızasal hâli, bir yapı olarak dursun ya da durmasın, çocukluk evinin asıl resmini içeren kaynağı teşkil ediyor. Dolayısıyla, hafızada yer etmiş bu geçmiş

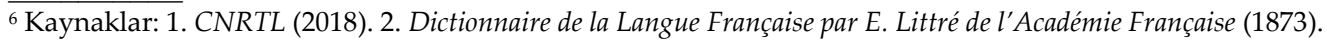


zamana ait ev resmi, gezgin-yazarı nostaljik bir özne olarak nitelememizi mümkün kılan en önemli kıstas oluyor.

Bu makalede yurt sözcüğü ile kastettiğimiz şey, sosyolojik ve ideolojik anlamindan ziyade, daha çok Fransızca chez-soi kelimesinin işaret ettiği salt anlamlara denk geliyor. Dolayısıyla yurt da ev gibi bir "ruh hâli" ile özdeşleşme durumu gösteren sembolik değeri yüksek bir mekân olarak kendini gösteriyor. Yani, yurt ile kastettiğimiz mekân, ev kavramının nitelediği dar, kapalı, birlikte yaşanılan ve sınırlı alandan ziyade, gezgin-yazar tarafından benimsenmiş herhangi bir mekân olarak düşünülebilir. Bu minvalde, çocukluğun geçtiği ev, psişik boyutu düşünüldüğünde, yurt olma özelliği de barındırabiliyor. Bu iki kavramın, daha geniş bir anlam olan chez-soi kavramı bünyesinde barınması bizim de, bu bağdaşıklığı, “öz-yer” kavramı bünyesinde değerlendirmemize yol açıyor.

Gezgin-yazarın çocukluğunda, kendini evinde, öz-yerinde hissettiği ev dışı mekânlar da bulunuyor. Yeni Zelandalı yazar Janet Frame, Towards Another Summer" adlı eserinde "özyerim" olarak nitelediği tozlu bir yoldan ve onu kuşatan birtakım değişik ögelerden meydana gelen ve bir an süren özel bir mekândan bahsediyor: "Öz-yerimi bulduğumda üç yaşımdaydım. Bu öylesine zihnimde derine işlemiş bir anı ki her zaman değişiyor, hiçbir zaman değişmiyor." diyen yetişkin gezgin-yazar Frame, yarattı̆̆1 alter ego roman karakteri Grace Cleave aracılığıyla, öz-yerini şu şekilde aktarıyor: “Tozlu yolda tek başımaydım. Yaz mevsiminin son günleriydi. Çitlerde, yaprak uçları kahverengiye dönen karaçalı çiçekleri buruşuyor ve yere düşüyordu. Rüzgâr tarafından telaşlı bir şekilde sürüklenen birkaç beyaz bulutun olduğu gökyüzü gri renkteydi. Hiçbir yerde insan yoktu; ne tozlu yolun ilerisinde, ne gerisinde. Uzağa baktım, yakına baktım, yol boyunca baktım, yolun ötesine baktım, tek bir insan bile yoktu. Burası benim yerim, dedim, bir yandan burada durmaya devam edip, bir yandan etrafıma kulak kabartarak." (2007: 59)

Öz-yerinde beklerken etrafına kulak veren Cleave bize ıssız bir mekân resmi çiziyor. Kendisinden başka insanın olmadığı bu yerde duyduğu rüzgâr uğuldamalarından bahsediyor. Yol boyunca tozların havada dönerek uçuştuğunu gören yazar, bu durumu şöyle değerlendiriyor: "Benim yerimde bir süre kaldım ve bu süre boyunca gittikçe daha yalnız hissettim, zira karaçalı çiçeklerinin olduğu çit benimdi, tozlu yol benimdi, rüzgâr ve onun telgraf telleri boyunca çıkardığı uğuldama benimdi. Kendi yerimdeyken hissettiğim yalnızlık duygusunu tarif edemem. Sahiplenmenin ağır yükünü öğrenmek, sizden başka birine verilmesi mümkün olmayan bir şeye ya da sizden koparılamayacak ve sonsuza dek muhafaza etmeniz gereken bir şeye sahip olmak için çok genç bir yaştaydım." (2007: 59)

"Benim yerim"8 diye tanımladığı mekânı aidiyet duygusu üzerinden betimleyen Frame, mekânı, o mekânda bulunan kişinin varlığından hareketle bir sahiplenme ilişkisinin parçası yapıyor. Bu şekilde mekân bir yurt, bir öz-yer, benimsenen, sahiplenilen bir durum hâlini alıyor. Çocukluk evinin aksine, Frame'in bize sunduğu yurt resmi, somut ve kesin sınırlardan yoksun, çatısı ve duvarları olan geleneksel anlamda kapalı bir mekândan ziyade, dört taraftan açık bir görüş açısına uzanan, ev sakinlerinin, içerisine belirli bir ruh hâli kattı̆̆ alışılmış bir iç mekândan farklı olarak, rastgele ve algı şaşırtıcı bir 1ssızlığın hüküm sürdüğü ve hissettirdiği ruh hâli yabancı ama bir o kadar da yakın gelen "garip" bir mekânı tarif ediyor.

\footnotetext{
7 “Bir Başka Yaza Doğru” olarak çevrilebilir. ${ }^{8} \mathrm{My}$ place.
}

SEFAD, 2018 (40): 1-22 
Üç yaşında iken, bir an için içerisinde bulunduğu mekânın kendisine ait olduğu hissini yaşayan gezgin-yazar, bir daha bu yerin zihninden hiç çıkmadığını, zihninde yer edinen bu mekâna ait resmin sürekli değiştiğini ama asla değişmediğini ifade ediyor. Burada Yeni Zelandalı yazar, evin ya da yurdun hafızasal yönüne işaret ediyor ki bu değişmemezlik/değişkenlik aslında tam olarak hafızada yer edinen ev resminin niteliğini, karakterini göz önüne seriyor. Zira yılların meydana getirdiği zamansal mesafe, gezginyazarın zihnindeki geçmiş ev resimlerini sürekli olarak canlı tutsa da onu durmadan değişime uğratıyor ve "benim yerim" diye nitelenen mekân, geçmişte benimsenen ve sahiplenilen bir öz-yer olarak kalmaya devam etse de bu mekâna ait resim, gezgin-yazarın zihninde her belirişinde farklı formlara bürünüyor, başka-yer oluyor.

Frame'in çizdiği öz-yer resmi, aidiyet duygusu hesaba katıldığında ve mekânsal niteliği bakımından yurt kavramı ile bağdaşma gösteriyor. Yeni Zelandalı yazar, "benim yerim" tabiri ile okura, hem ev hem yurt kavramlarını içine alan öz-yer terimini karşılayan bir betimleme sunuyor. Bu betimlemeden de anlaşılacağı üzere, söz konusu aidiyet duygusunu tetikleyen şey, gezgin-yazarın o an deneyimlediği yalnızlık ve bundan ötürü girdiği hissel vaziyet olarak karşımıza çıkıyor. Yalnız olarak deneyimlenen, sahiplenilmeyi bekleyen ve gezgin-yazarın hislerini doğrudan ve güçlü şekilde etkileyen mekân ev, yurt, öz-yer formuna bürünüyor ve bu hâliyle "benim yerim" oluyor.

Gezgin-yazarın ev/yurt algısı başka-yerde geçirdiği zaman zarfında, birtakım dış faktörlerin etkisiyle (kuraklık, evsizlik, yalnızlık gibi) bir nostaljik imaj olarak ortaya çıkabiliyor. Evin/yurdun kendine özgü şartları, ruh hâli diye adlandırabileceğimiz özel bir duruma neden oluyor ve bu durumun sonucu olarak, evin/yurdun sakini vasfı ile gezginyazarın zihninde bu mekânın çarpıcı bir resmi yer ediyor ve daha sonra, gezgin-yazar, artık bir yetişkin olarak, kendisiyle arasına kapatılamayacak şekilde mesafe giren çocukluğunun öz-yerine dair bu resmi zihninde taşımaya devam ediyor. Bu son derece bireysel ve soyut karakterde olan resim, başka-yerin kendine özgü şartları altında su yüzüne çıktı̆̆ında, gezgin-yazarın hissettiği duygular, edindiği izlenimler farklılıklar gösteriyor. Öyle ki bu bazen bir daha kavuşulamayacak bir mekâna duyulan ve şimdiki zamanı geçici olarak anlamsızlaştıran ve daha çok hüznü andıran bir özlem, bazen şimdiki zamana yeni ve tamamlayıcı bir anlam veren memnuniyet verici hoş bir hatıra, bazen de gezgin-yazara kendi gerçek öz yerini bulmuş olduğunu hatırlatan çok uzak ve kısa bir ana dair tuhaf bir resim olarak kendini gösteriyor. Bir başka ifadeyle, ruh hâli olarak ev ve yurt, gezginyazarın kişisel deneyimi aracılığıyla bir öz-yer oluyor ve zaman faktörü vasıtasıyla da nostaljik bir başka-yer hâline giriyor. Böylelikle, evin/yurdun sebep olduğu ruh hâli, gezginyazarın zihninde, düşsel ve duygusal boyutundan kaynaklı olarak romanesk sıfatı ile nitelendirebileceğimiz belli formlarda varlığını sürdürmeye devam ederken, geçmişe ait bu mekânın öz-yer karakteri, zamansal mesafenin etkisiyle, başka-yer karakterine dönüşüyor.

\section{Değişken Bir Unsur Olarak Ev ve Yurt}

Zaman ve mekân faktörlerinin sebep olduğu mesafe ev ve yurt kavramlarının anlamını, tanımsal ve betimsel çizgilerini değişime uğratıyor. Yetişkin kimliğiyle, başkayerde yabancı olarak bulunma deneyimi yaşayan gezgin-yazar, etkisi altında bulunduğu şartlardan hareketle bir mekâna dair sahiplenme ya da aidiyet duygusunu sorgulama eğilimine giriyor. "Benim yerim", "benim yurdum”, “evim” gibi öz-yer tanımlayıcı ifadeler üzerinden bir mekân betimi yapma durumu gösteren gezgin-yazar, bulunduğu güncel zaman ve mekân şartlarında "öz-yerim" olarak niteleyebileceği tek ve kesin bir yerin 
imkânsızlığının ayırdına varıyor. Çocukluk yıllarına ait anılardan hareketle zihnine ses veren ve bunu kelimelere döken gezgin-yazar, gerçek anlamda sahiplenebildiği mekânların bu uzak geçmiş dönemde kaldığını ifade ettikten sonra, içinde bulunduğu şartlar içerisinde var olan mekânların kendisinde kesin ve değişmez bir aidiyet duygusu uyandırmaya tek başına yetmediğini, bu şekilde bir sahiplenme bağının oluşmasına mahal vermediğini ifade ediyor. Zira bir yere ait olduğu hissi, yetişkinliğin ve gezginliğin sebebiyet verdiği şüphe duygusuyla beraber çözümlenemez bir soru vasfına bürünüyor.

Bir alg1 objesi olarak mekân, bir algı öznesi olarak insana nazaran, devamlı olarak bir (somut veya somut) şekil değiştirme durumunda bulunuyor. Kurgusal eseri Espèces d'espaces'ta9 mekân ve aidiyet mevzusuna değinen Fransız yazar Georges Perec, bu mesele ile ilgili olarak beslediği bir arzusundan şu kelimelerle bahsediyor: "Kalıcı mekânların var olmasını isterdim, değişmeyen, sabit, dokunulmaz, el değmemiş, hareketsiz, kök salmış mekânlar: "çıkış noktası", "referans", "kaynak" olabilecek mekânlar." Daha sonra, "doğduğum ülke, ailemin yurdu, doğduğum ev, doğumumla beraber babam tarafından ekilen ve büyüdüğüne şahit olduğum ağaç, dokunulmamış hatıralarla dolu çatı katı" şeklinde öz-yer listesi çıaran Perec, mekânın bir şüpheden ibaret olduğunu ve insanın onu devamlı olarak fethetmesi gerektiğini, zira mekânın "bana ait" olmadığını ya da "bana verilmiş" bir yer olmadığını, mekânı hiç durmadan işaretlemek, belirtmek gerektiğini belirten Fransız yazar, şöyle devam ediyor: "Benim mekânlarım kırılganlar: zaman onları yıpratacak, yok edecek, hiçbir şey var olmuş olan şeye benzemeyecek, anılarım beni aldatacak, unutma denen şey hafızamın içerisine nüfuz edecek." (2000: 179-180)

Perec'in "değişmeyen" mekân arzusu ve tarif ettiği öz-yer resmi, hiç kuşkusuz nostaljik ev/yurt imajı ile ilişkili olarak düşünülebilecek bir noktaya bizi götürüyor. "Benim mekânlarım" diye nitelediği alg1 objelerinden hareketle, bir alg1 öznesi olan insan için mekânın kırılganlığını vurgulayan yazar, ne kadar sahiplenilirse sahiplenilsin, mekânın değişimden kurtulamayacağını, başkalaşacağını, "benim" olarak nitelendirilmeye devam etse de aynı kalamayacağını, "kök salamayacağını" belirtiyor.

Zaman faktöründen ve insan algısının değiştirici etkisinden soyutlanmış bir mekân fikri, ruh hâli olarak mekân fikri ile kıyaslandığında iki ayrışık durumu bize sunuyor. Nitekim, her ne kadar Perec'in kök salmasını istediği mekânlar ruh hâlinin anlam verdiği öz-yerler olsa da, ruh hâlinin zaman ve insan algısı ile olan sıkı bağı, "değişmeyen mekân" ideali ile ters düşüyor. Bununla beraber, algılayan özne olan insanın "benim yerim" diye benimsediği mekânların dahi aynı kalmadığını, başka-yer hâline dönüştüğünü, zihninde yer edinen ev resimlerinin unutma denen indirgeyici/dönüştürücü sürece maruz kalmaktan kurtulamayacağını yine Perec bize hatırlatıyor. Peki, evin ve yurdun bu değişken karakterini, gezi edebiyatı okuyucuya nasıl aktarıyor?

Çağdaş gezi edebiyatının temsilcilerinden biri olan Türk yazar Enis Batur, bir yirmi birinci yüzyıl eseri olan Başka Yollar'da, zaman-mekân-insan ilişkisine dair şöyle bir tespitte bulunuyor: "Zaman ve Uzam, bir parçalarına ayrışır oldu zihnimde, bir bütünleştiklerine vardım. İnsana, bir de, gün geliyor, Çağını ve Beldesini hepten yitirmiş olduğu korkusu çöküyor -Yaşamak ne zor şey." (2013: 180) Ev/yurt algısının çözümlenmesi bağlamında Batur, şahsî algısını merkeze koyarak, "Zaman" ve "Uzam" kavramlarına bir tanımlama getirmeye çalışıyor. Lâkin bu tanım, kesin çizgilerden uzak, bir belirsizlik ve şüphe

${ }^{9}$ Türkçeye "Mekân Cinsleri" diye çevrilebilir. 
yansitıyor. Organik ögeler olarak ele aldığı ve büyük harfle başlatarak vurgusunu yaptığ1 "zaman" ve "uzam" kavramlarının zihnindeki resminin ne denli girift olduğunu dile getiren gezgin-yazar, bu resme dayanarak, yaşamak eylemiyle bağdaştırdığı bir korkudan bahsediyor. "Çağını ve Beldesini hepten yitirmiş olmak" tabiriyle bu korkuyu okuyucuya aktarma yoluna giden Batur, ev ve yurt denen mekânlara sahip olamamanın sebep olduğu ruh hâlini, "yitirmek" fiili ile anlatıyor.

Zamanında sahip olunmuş mekânları, "benim mekânlarım" diye adlandırılabilecek yerleri artık kaybetmiş olmak, bu yerlerin değişmesi, tamamı ile başka-yerler hâlini alması ile gezgin-yazarın ev/yurt algısı değişime maruz kalıyor. Bu değişkenliği, sabitlenemezliği bir korku kaynağı olarak gösteren gezgin-yazar, "öz-yerim” ifadesinin aslında, yitirme hissi ile, ki Perec bunu unutma hâli ile açıklamıştı, kol kola giden bir mekân ve zaman fikrine bağımlı olduğunu bize düşündürüyor. Yine, mekânın değişken karakteri ve insan-mekân ilişkisi ile ilgili olarak Batur, kitabının başka bir yerinde, bu kez farklı bir bakış açısından hareket ederek insan algısı merkezli bir başka yaklaşım sunuyor: "Kendimi bir yurda bağlayamayacak ölçüde uzak düştüm evimden. Onu aramayı elden bırakmadım ama. Sözgelimi [...] hiçbir yerde duramayan bünye değil benimkisi, tersine pek çok beldenin yerlisi olmaya yatkın olduğum için yurtsama duygusundan geniş çapta arınmış duyarlığım: Bana burayı verin, hemen yaşamaya koyulurum." (2013: 209)

Yukarıdaki tanımında "yurtsamak" tabiriyle karşımıza çıkan Batur, kendi yurt algısının belli bir mekândan bağımsız oluşunun, her beldenin "yerlisi" olmaya meyilli biri oluşunun vurgusunu yapiyor. Batur burada bize ev ve yurt betimlemesi yaparken, bu mekânları tanımlayan çizgilerin mutlak belirsiz bir karakter taşıdıklarını, dolayısıyla tek bir yurdu olamadığını, tek bir yeri, yurdu diye benimseyemediğini, her mekânın yurdu olabileceğini belirtiyor. Bununla beraber uzak düştüğü bir ev, bir öz-yerden de bahseden gezgin-yazar bu uzaklığın kendisinde bir mekâna bağlanma hissini iyiden iyiye imkânsızlaştırdığını ancak buna rağmen sahiplenebileceği bir mekân arayışının hâlen devam ettiğini söylüyor. Bu ifadeler bir arada düşünüldüğünde, gezgin-yazarın zihnindeki öz-yer algısının hangi boyutta bir belirsizliğe işaret ettiğini irdelemek mümkün oluyor. Buna göre, bir daha bulunmamak üzere uzaklaşılan öz-yer, bu uzak mekânı yeniden bulma hayaliyle arayışını sürdüren gezgin-yazar, kendisini her mekânın yerlisi gibi ama hiçbir mekâna tam olarak ait görmeyen algılayıcı özne olarak insan, zaman-mekân-insan ilişkisi söz konusu olduğunda, Perec'in bahsettiği kök salamama durumunu doğrular bir devinimin parçası oluyor.

Mekânın değişkenliği ile bağlantılı olarak, bir başka gezgin-yazar, Saint-Exupéry, evin ve yurdun değişkenliğini, insan-medeniyet-mekân ilişkisi üzerinden sorguluyor ve insanların, mekânın değişkenliği karşısında muhafaza ettikleri sonsuzluk hissine gönderme yapıyor: "Hâlen ılık olan bir lav üzerinde felakete uğrama riski ile karşı karşıya iken ve ileride gelecek olan kumların ve karların tehdidi altında iken, insanlar bu sonsuzluk hissini nereden alıyor? İnsanların medeniyetleri kırılgan bir süs eşyasından başka bir şey değil: Bir volkan onu siliyor, sonra yeni bir deniz beliriyor, sonra bir toz fırtınası kendini gösteriyor." (2007: 58) Fransız gezgin-yazar, insanın evi/yurdu olan dünyanın değişkenliği karşısında insanların meydana getirmiş oldukları ve getirecekleri medeniyetlerin ne derece kırılgan olduğunu vurguluyor. Saint-Exupéry, mekânın değişken karakterinin kaçınılmaz bir durum olduğunu ve her tür mekânın, az veya çok, değişme sürecinden etkilendiğini, dolayısıyla insanın da bu değişimin zoraki parçası olduğunu belirtiyor. 
Batur'un, mekânı algılamada tek bir kişinin yurdu olma fikrini merkeze koyan şahsî bakış açısından farklı olarak, Saint-Exupéry, mekânı en geniş anlamı ile bir obje olarak irdeleyip, insanlığın mekân ile olan ilişkisi üzerine evrensel ölçekte bir gözlemde bulunuyor. Mekânın değiştirici, yıkıcı, onarıcı, tehditkâr değişkenliğe rağmen insanın, yaşadığı mekânı bir ev/yurt, bir öz-yer hâline getirme isteğinin tükenmeyen kaynağının nereden geldiği sorusunu ise, yine bir insan olarak, gezgin-yazar cevapsız bırakıyor. Böylelikle, ev/yurt tanımı, insan-mekân-zaman döngüsü içerisinde ele alındığında sınırları kesin olmayan bir kavram olarak kalmaya devam ediyor. Bu muğlaklık, evin ve yurdun bir öz-yer olarak benimsenmesinde şüphe faktörünün ayrılmaz bir bileşen olarak karşımıza çıktığını teyit ediyor ve değişken bir mekân olarak ev ve yurt kavramı ile bir bağdaşıklık durumu içine girmiş oluyor.

Mekânın kırılganlığı ve değişkenliği üzerine saptamada bulunan gezgin-yazar, bize, insanın mekân ile olan ilişkisinin basit bir tanıma indirgenemeyecek kadar karmaşık nitelikte olduğunu gösteriyor. Başka-yer deneyimi ile bu karmaşıklık daha belirgin ve hissedilir hâle geliyor. Zira başka-yere ulaşmanın sonucu meydana gelen mesafe, öz-yer kavramına, dolayısı ile ev ve yurt kavramlarına daha objektif ve sorgulayıcı bir açıdan bakmayı olanaklı hâle getiriyor. Yani, bir yandan evi/yurdu nostaljik bir resim hâline getiren mesafe, aynı zamanda bu sembolik mekânın sorgulanabilir olmasına yol açıyor, onu bir şüphe objesi hâline sokuyor.

\section{Kapalı Bir Mekân Olarak Ev ve Yurt}

Şimdiye kadar üzerinde durduğumuz mekânın nostaljik ve değişken olma özellikleri, hiç şüphesiz, ev ve yurt kavramlarının, daha genel anlamda "öz-yer" kavramının çizgilerinin belirsizliğini ön plana çıkarıyor. Geçmiş zamanda deneyimlenmiş bir ruh hâlinden kaynaklanan ve bir mekân ile doğrudan ilişkili olan kişisel bir duruma dair gezginyazarın okuyucuya aktardığı "öz-yer" betimi, ev ve yurt algısının daha çok soyut boyutunu temsil ediyor. Ancak, bu makale, öz-yer kavramına olabildiğince kapsayıcı bir tanım getirme açısından ev ve yurt algısının farklı ve tamamlayıcı boyutlarını göstermeyi amaçladığından, bu bölümde, evin ve yurdun, sınırları az ya da çok belirgin, somut bir mekân olarak tanımlanmış resmi gözlemlenecek. Böylelikle, nostaljik ve hissel ağırlıklı boyuttan fiziksel odaklı boyuta bir geçiş yapılmış da olacak.

Habiter: le lieu et son atmosphère ${ }^{10}$ adlı makalesinde evin iç mekânını bir barınma, hayatta kalma yeri olarak niteleyen Fransız filozof Francis Esquier, bu barınma mekânının içinde yaşayan "algılayıcı özne" olarak insanın, ikamet ettiği bu mekâna ait olduğunu belirtiyor. Esquier'e göre, evin iç mekânı, içerisinde bulunduğu sürece bu mekânın parçası olan insana, dış mekâna nazaran neredeyse değişmeyen, özel bir alan sunuyor. Bu "neredeyse değişmemezlik", evin sığınma yeri olma vasfını besleyen bir özellik olarak anlaşılıyor ki dış mekânın değişkenliğe ve belirsizliğe açık vaziyeti, anlaşılacağı üzere, bu özelliği pekiştiriyor. İç mekân-dış mekân diyalektiğinden hareketle evin fiziksel karakterine değinen Esquier, evin, onun içerisinde ikamet eden kişi için bir nevi "otonomi üstlenme alanı" özelliği gösterdiğini ve dışarıdan da tam olarak bu noktada, belirgin bir şekilde, ayrıştı̆̆ını söylüyor.

Evin fiziksel sınırlarla belirlenmiş ve dış mekândan bu şekilde ayrıştırılmış iç mekânı, önceki iki bölümde öne sürdügümüz evin sınırsal açıklığı ve belirsizliği durumunun tersine,

10 “İkâmet Etmek: Mekân ve Onun Sunduğu Ortam” şeklinde Türkçeye çevrilebilir.

SEFAD, 2018 (40): 1-22 
belirli bir alansal darlık ve kesinlik vaziyeti meydana getiriyor. Esquier'in sözünü ettiği neredeyse değişmemezlik durumu, eve, ki yurt kavramı anlamsal niteliği nedeniyle aynı darlığı sağlamıyor, kolayca algılanabilir olma hâlini kazandırıyor. Bu fiziksel sınırlılık ve kapalılık özelliği, ev tanımını tarif edilmesi daha basit bir düzleme oturtma imkânı veriyor.

Kapalı bir mekân olarak ev ve yurt başlığı altında, sınır meselesiyle beraber, daha önceki başlıklar altında yer verilen aidiyet meselesi dikkate değer bir başka algısal konu olarak ortaya çıkıyor. Ancak, bu defa, aidiyet, ikamet eden sakinin, ya da bir başka deyişle, algılayıcı özne olan insanın, ikamet ettiği fiziksel mekânın sınırlarının içinde yer alan iç mekâna ait olması şeklinde kendisini gösteriyor. Janet Frame'in, yukarıda bahsettiğimiz, dört bir yana uzanan ve sınırları açık öz-yer betiminde, algılayıcı özne olarak etrafındaki ögeleri kendisine ait olarak algılaması durumuna karşıt olarak, evin kapalı karakteri, iç mekânı içinde "barınan", dolayısıyla pasif duruma düşen algılayıcı özneyi "mekânın sahibi" konumundan "mekâna ait olan" pozisyonuna devşiriyor. Öyleyse, mekânın kapalılı̆̆ı ve değişmemezliği, ev ve yurt algısına, algılayıcı özne olan insan açısından sahiplenilen bir obje olmaktan ziyade kendisine bağlı hâle gelinen bir iç ortam boyutu edindiriyor. Söz konusu boyutun çağdaş gezi edebiyatındaki karşılığını görmek ve bu bölümün başlı̆̆ına teorik bir zemin kazandırmak adına, bu çalışma için referans olarak alınan eserlerdeki tanımlamalara bakmak gerekiyor.

Başka-yerde deneyimlediği bir gezi esnasında, Fransız gezgin-yazar Saint-Exupéry, Arjantinli bir ailenin evine konuk olarak çağırılıyor. Bu mekânı dışarıdan gördüğü ilk anda, gezgin-yazar şu ifadeleri kullanıyor: "Ne tuhaf bir ev! Neredeyse bir kale! Eşiğini aştı̆̆ınız anda bir manastır kadar güvenli, emin, huzur verici bir sığınağa girmiş oluyorsunuz." (2007: 68) Kapalı bir mekân olarak evi bir sığınağa benzeten Saint-Exupéry, burayı, dış mekâna kıyasla güven verici, huzur dolu bir yere benzetiyor. Kaleyi andıran dış görünüşüyle ilk andan itibaren gezgin-yazarın algısını etkileyen bu yabancı ve "tuhaf" ev, iç mekânıyla bir ruh hâlini anımsatıyor. Başka-yerin sınırları içerisinde bir sığınak gibi görünen bu yabancı evin dış görünümü ve iç mekânı, gezgin-yazarın zihninde güven verici bir öz-yer resminin canlanmasına neden oluyor. Bu mekânın sakini olmamasına ve burada ilk kez bulunmasına rağmen gezgin-yazar, fiziksel niteliğinden ötürü bir barınma ortamı imajı sunan bu öz-yerin, insana verdiği kesinlik, kapalılık ve devamlılık izlenimini okuyucuya "konuk" vasfı ile aktarmış oluyor. Kaleyi andıran bu ev, sınırları vasıtası ile sahip olduğu mekânsal otonomi sayesinde bir anlamda kendisine bağlanılma hâli yaratıyor, algılayıcı özne olan insanı bir aidiyet ilişkisinin bir bakıma edilgen parçası yapıyor. Evde ikamet etmekte olan sakin, otonom, yani dış dünyanın uçsuz bucaksızlığından ve algıyı şaşırtan resminden ayrışmış olan bu kapalı mekâna, bu öz-yere kendisini ait hissediyor, sakin olabilmesini, bu neredeyse değişmeyen mekânla ilişkilendiriyor, evi etken bir pozisyona yükseltiyor.

Başka-yerde bulunduğu zaman dilimi içerisinde karşılaştığı, içinde bulunduğu kapalı mekânları bir yabancı gözüyle algılayan gezgin-yazar, mekânın kapalılı̆̆ının farklı boyutlarına şahit oluyor. L'Africain $d u$ Groenland ${ }^{11}$ adlı yirminci yüzyıl çağdaş gezi edebiyatı eserinin yazarı olan Togolu gezgin-yazar Kpomassie, Grönland'da bulunduğu zaman içerisinde kapalı mekân algısını değiştirecek deneyimler yaşıyor. İlk olarak, buradaki evlerin dış kapılarının hiçbir zaman kilitlenmediğini, zaten bu kapıların anahtarlarının da olmadığını gözlemleyen Kpomassie, şaşkınlığını kitabı aracılı̆̆ı ile okuyucuya aktarıyor.

11 "Grönland'daki Afrikalı" olarak Türkçeye çevrilebilir 
(1981: 108) Bir özel mekân olarak algılayageldiği evin bu şekilde dış mekâna karşı "korunaksız" olduğunu gören gezgin-yazar, daha sonra yaşadığı bir başka deneyimde, bu kez "hapishane" olarak kullanılan bir yapının sıradan evler gibi göründüğünü anlatıyor ve kapalılığın en üst seviyede gerçekleşmesi beklenen bu mekânda bulunan mahkûmların gündüzleri dışarıda çalışmak üzere serbest bırakıldıkları öğreniyor. (1981: 135-137) Bu betimlemeleriyle, dış mekân-iç mekân ayrışmasının, Saint-Exupéry'nin tarif ettiği “kale gibi ev" tanımından farklı bir boyutunu sunan Kpomassie, bize, bir yabancı gözüyle, kapalı bir mekân olarak evin dışarı ile tamamen ayrışmamış, belirli fiziksel sınırlara sahip olsa da içinde ikamet edenlere bütünüyle hususî bir öz-yer sunmayan özelliğini gösteriyor. Bunu gezgin-yazar, başka-yerin ona sunduğu şartlar sayesinde bizlere aktarıyor.

Öz-yerinden uzaklaşıp belirli bir mesafe kat ettikten sonra başka-yere ulaşan gezginyazar, başka insanların ikamet ettikleri öz-yerleri gözlemleyince, zihnindeki mevcut ev ve yurt tanımını, resmini yeniden düzenlemek durumunda kalıyor. Kendi evinin kapalı sınırlarının ötesine geçerek, başka yurtların sınırlarının içerisine giren gezgin-yazar, bu uzak ve özel mekânların kendisinde yarattığı izlenimleri "başka-yerdeki başkasına ait olan özyer" koşulu altında bir ev resmi çizerek okuyucuya aktarmış oluyor. Fiziksel sınırları sayesinde dış mekânın değişkenliğinden bir şekilde korunan evin dış görünüşü ve iç mekânı, başka-yeri deneyimlemek için kendi evinin iç mekânından uzaklaşan gezginyazarın kelimeleri aracılığıyla "farklı bir ev", "tuhaf bir öz-yer" tanımına sebep olmuş oluyor. Bu farklılık durumu, evin ve yurdun bir yandan tanımsal olasıliklarını arttırırken, diğer yandan algısal tanımını daha karmaşık bir hâle sokmuş oluyor. Başka bir ifadeyle ev ve yurt resmi, başka-yer deneyiminin etkisiyle, keskin ve monoton çizgilerinden arınıyor, eklektik, karmaşık, kişisel ve çok yönlü bir tanım kazanıyor. Kpomassie'nin, dışarıdan tamamen soyutlanmamış hapishane betimi ya da anahtarı olmayan ev betimi bu çok yönlülüğün karşılık bulmuş hâli oluyor.

Alansal kapalılık ve fiziksel sınırlılığın getirdiği dış mekândan ayrışma niteliklerine rağmen ev, dış mekân-iç mekân ilişkisi bağlamında farklılıklar gösterebiliyor. Bir yandan kale gibi korunaklı ve kapalı bir form özelliği gösterebilirken, diğer taraftan kolayca içine girilebilecek bir mekân izlenimi verebiliyor. Ancak, söz konusu kapalılığın derecesi ne olursa olsun, ev ve daha geniş anlamıyla yurt, kapalılığını belirleyen sınırlar içerisinde aynı zamanda birtakım işaretler barındırıyor. Ev ve yurt, ikamet eden algılayıcı özne olan insan ile beraber bu sembolik ögelere barınak oluyor. Evini ya da yurdunu bu işaretlerle paylaşan, tıpkı bu işaretler gibi evin ve yurdun bir parçası olan, ikamet eden özne olarak insan, başkayer deneyimi sırasında evle beraber bu işaretlerin de değiştiğini, farklılaştığını ya da benzeşebildiğini gözlemleme imkânı buluyor.

Bir evi ya da yurdu dolduran sembolik işaretler, o mekânın karakteri hususunda, algılayıcı özne vasfıyla bir yabancı olarak başka-yerde bulunan gezgin-yazara birtakım fikirler veriyor. Bu işaretler, ev ve yurt algısının bütünlügü açısından önemli bir rol oynuyor. Zira insan, yaşamını geçirdiği özel ve kapalı bir mekân olan evini, kendisi için işlevsel ya da manevi değeri olan birtakım nesnelerle doldurma eğilimi gösteriyor. Burada, ev, bir işaretler mekânı olarak, insan ve kimlik ilişkisi bağlamında göstergesel bir rol ediniyor. İnsanın kimliğini sembolize eden bu işaretler, evin sınırları içerisinde muhafaza ediliyor, böylece bir devamlılık kazanıyor. Aynı durum yurt kavramı için de geçerli oluyor. Nitekim eve nazaran daha geniş bir mekânı kendine özel sınırları aracılığı ile içine alan yurt, içerisinde onu tanımlayan birtakım sembolik işaretler barındırıyor ve yine bu durum bir devamlılık 
durumunun meydana gelmesine neden oluyor. Yani, ev ve yurt, sınırlılıkları ile bağlantılı olarak, içerilerinde yer alan işaretlerin bütünü ile beraber mekânsal bir devamlılı̆̆ın bileşenleri oluyorlar ve bu bileşenler, o ev ve yurdun öz-yer niteliğini tanımlayan otantik (eskiden beri mevcut olan özelliklerini taşıyan) ögeler hâline geliyor. Ancak, diğer hususlarda olduğu gibi, bu noktada da, başka-yer deneyimi sayesinde, gezgin-yazar, tanımları çoğullaştırarak farklı bakış açıları edinmemizi sağlıyor.

İsviçreli gezgin-yazar Nicolas Bouvier, yirminci yüzyll ürünü olan Le poisson-scorpion ${ }^{12}$ adlı eserinde, Sri Lanka'daki başka-yer deneyiminden hareketle, bir yurdu dolduran işaretlerin, o yurda has işaretlerin yanında, dış yurtlardan yani başka-yerlerden getirilmiş işaretler de olabileceğini belirtiyor: "Kendi örflerimizi, ölçülerimizi, meridyenlerimizi, Tanrılarımızı [başkalarına] dayattık, coğrafyayı yalnızca kendi çıkarlarımıza alet ettik. [...] Birkaç yüzyıl boyunca Hıristiyan Batı merkez, Dünya da Avrupa'nın banliyösü oldu." (2011: 69)

Yukarıdaki sözleriyle, gezgin-yazar, bize yurdun kapalılı̆̆ının farklı boyutlarını gösteriyor. Bu kapalılık, dış etkilere açıklık faktörü ile yeniden tanımlanıyor. Bu şekilde bir etkileşim, bir yurdu dolduran işaretlerin de değişmesine sebep oluyor ve yurdun kapalılığının sağladığı devamlılık bir şekilde sekteye uğramış oluyor. Bu durum, aynı zamanda yurdun değişkenliğinin altını bir kez daha çizmiş oluyor ki, sınırlarına rağmen birbirlerine erişebilirlik noktasında aynı yeryüzüne ait olan evler ve yurtlar dış etkilere az ya da çok seviyede açık mekânlar olarak varlıklarını sürdürme durumu gösteriyorlar. Öyle ki bu açıklık durumu sınırların değişmesine, böylelikle yeni yurtların ortaya çıkmasına, farklı yurtların birleşmesine, mevcut yurtların yeni bir mekânsal kimliğe bürünmesine sebebiyet verebiliyor. Bu da evin ve yurdun bütünlüğünü tayin eden sınırların yapaylığı sorusunu akla getiriyor.

\section{Yapay Bir Alan Olarak Ev ve Yurt}

Sınırları açışından irdelendiğinde, yurt da, tıpkı ev gibi, içerisi işaretlerle doldurulmuş büyük bir ev fikri veriyor. Nitekim modern anlamda ev, yurdun sınırları içerisinde var olan bir ikamet yeri olarak kabul edilebilir. Evin sınırı, dar anlamda düşünüldügünnde, yurdun sınırı içerisinde kalıyor; öz-yer kavramından hareket edildiğinde ise evin ve yurdun sınırları ayırt edilemez bir hâle gelebiliyor. Öz-yer kavramının şahsî, soyut ve hissel boyutu bir yana, ev ve yurt kavramlarının tarif ettiği ve sınırlar vasıtası ile tanımlanmış kapalı mekânlar, kendi içerilerinde bir devamlılık, neredeyse değişmemezlik sağlamak adına, aslında tek bir doğal alan olarak düşünülebilecek yeryüzünü daha küçük alanlara bölüştürüyor, onu tek bir alan olmaktan çıkarıyor, alansal çoğulluğa sebep oluyor. Tek bir alanın devamlılığını ortadan kaldıran bu tür bir kapalılaşma ve sınırlandırma durumunun sonucu olarak karşımıza yapay olarak niteleyebileceğimiz mekânlar ve bu mekânların tanımladığı ya da bu mekânları tanımlayan ev ve yurtlar çıkıyor.

Bir yurdun sınırı, başka yurtların sınırları ile göreceli bir ayrışmanın zeminini hazırlayan başat faktör olarak kendini gösteriyor. Yapay sınırlarla tanımlanmış bir mekân, bir yandan bu sınırların içinde kalan alanın bir öz-yere dönüşmesine, öte yandan bu sınırların dışında kalan alanın başka-yere dönüşmesine neden oluyor ve bu alana nazaran kendisi de başka-yer hâlini alıyor. Dolayısıyla, tek olan alan, başka-yerlere dönüşerek, çoğullaşarak, kendisi de artık başka-yerlerden meydana gelen bir başka-yer oluyor. Bununla

12 "Aslanbalığı" olarak Türkçeye çevrilebilir. 
ilgili olarak, Fransiz filozof Paul Ducros, Fransizca terre ve territoire kavramlarından hareketle, bir bütün olan ve doğal anlamıyla ele aldığı terre yani toprağın/yeryüzünün nasıl bir parçalanmaya ve yapay anlamda territoire yani bölgeleşmeye/toprak parçası olmaya gittiğini şu sözlerle ifade ediyor: "Toprak parçasının içinde toprağın/yeryüzünün kendisi artık yok oldu. [...] Toprak parçasının anlamı, onun, en sonunda kendi başına bir olgu olarak algılanacak şekilde, bir topluluğun üyeleri ile devamlı olarak mevcut olan alansal ilişkisinden geliyor." (2011: 267)

Evin ya da yurdun yapaylığı, onun toplumsal ve uzlaşımsal tarafına işaret ediyor. Sınırları yapay nitelikte olan modern ev ve yurt, bu yapaylığın toplumsal boyutta kabul görmesiyle uzlaşımsal yapaylık olarak niteleyebileceğimiz bir durumla bizi karşı karşıya bırakıyor. Zira evi ve özellikle de yurdu tanımlayan bu yapay sınırlar, toplum ölçeğinde öğrenilen, benimsenen ve öğretilen bir kimliksel gerçekliğe evriliyor. Yaşamını sürdürdüğü evin sınırlarını öğrenen insan, daha sonra bu evin de içinde yer aldığı yurdun sınırlarının bilincine varıyor. Doğal karakterde olmayan bu sinırlar, ya da Ducros'nun deyimiyle "tek ve doğal olan toprağı bölüştüren yapay toprak parçaları" (2011: 267), evin ve yurdun birtakım somut ya da soyut işaretlerle kendine has bir yaşam alanı hâline dönüşmesine sebebiyet veriyor. Burada, yine, kimlik meselesi ekseninde bir mekân algısı durumu ortaya çıkıyor. Bir uzlaşı olgusu olarak kimlik, mekânsal gerçeklikle paralel bir yol izliyor ve kimliği tanımlayan işaretler ile evi ve yurdu tanımlayan işaretler arasında bir etkileşim söz konusu oluyor. Bahsettiğimiz yapay sinırların sebep olduğu bu öz-yer durumu, gezgin-yazar tarafından, kendi yurdunun sınırları dışında bulunan bir yabancı gözüyle, farklı açılardan irdeleniyor, sorgulaniyor ve okuyucuya ev ve yurt algisına dair bir fikir veriyor.

Mekânın yapaylığı mevzusu ile ilintili olarak, Yeni Zelandalı gezgin-yazar Frame, yurt kavramını aidiyet ve gerçeklik kıstaslarını baz alarak değerlendiriyor: "[...] hani şu gerçekliği olmayan yanılsatıcı yere, "kendi ülkelerine" döndüklerinde ("kendi kelimelerim" -kimin kelimeleri?- ile yazılmış olduğunu iddia eden bir yazı misali) [...]." (2007: 133)

Kelime ve yurt kavramlarını yapaysallık paydaşında ele alan gezgin-yazar, tıpkı kelimeler gibi yurdun da gerçekte var olmayan, uzlaşımsal bir yapay yaratı olgusu olduğunu vurguluyor. Kelimelerin gerçek anlamda hiç kimseye ait olmadığını ifade eden Frame, yurdun da aynı şekilde hiç kimseye ait olamayacağını, onun, kelimeler gibi, kavramsal soyut bir olgudan öte bir şey olmadığını belirtiyor. Kelimeler ile yurdu benzeştiren bu bakış açısı; kendini ifade etmek, dünyayla bağını canlı tutmak adına soyut ve uzlaşısal bir olgu olan kelimeleri kullanan insanın hayatında, yine soyut ve uzlaşısal olduğu varsayabilecek yurdun yeri nedir sorusunu akla getiriyor ve şu soruyu sorduruyor: "Yurt da tıpkı kelimeler gibi insan hayatının bir vazgeçilmezi midir?"

Evin ve yurdun yapay sınırlarına farklı bir yorum getiren, bir başka gezgin-yazar, Saint-Exupéry, insanın kendini "tamamlayabilmesinin" yaşadığı mekânın gerçekliğiyle bağlantılı olduğunu öne sürüyor ve "eğer ki bir başkası değil de şu din, şu kültür, şu değerler bütünü, şu yaşam biçimi ise insanın içindeki potansiyeli gün yüzüne çıkaran ve onun kişiliğini tamamlayan, o hâlde insanın hakikati bunlardır. Mantık nerededir burada? Varsın biraz da mantık, hayatı anlamak için çabalasın!" (2007: 159)

Saint-Exupéry, insanın hakikatini yurt kavramından hareketle açıklarken, bu yurtinsan-hakikat ilişkisinin, "işaret" olarak adlandırabileceğimiz sembolik değeri olan birtakım kültürel olguların meydana getirdiği kimliksel ögeler bütünüyle doğrudan ilişkisi olduğunu 
savunuyor. Burada, bir ağacın yeşerip meyvelenmesine olanak sağlayan toprağı, o meyve ağacının mekânsal hakikati olarak ele alan Saint-Exupéry, böylece, yurt kavramını, insanın karakterine, gelişimine olan katkısı noktasından hareketle, özellikle insanın doğduğu ülke, yerleşim yeri olarak değil de insanın kendini tamamlayabilmesine elverişli herhangi bir mekân, bir öz-yer olarak tanımlıyor. Bu yaklaşım ile Saint-Exupéry, yurt kavramını tanımlayan sınırların kişisel ve rölatif (izafî) bir karakter taşıdığını ve bu özel mekânın aslında evrensel yönünü vurgulamış oluyor.

Başka-yer deneyimi edinmiş olan ve farklı yurtların farklı işaretlerine şahit olan gezgin-yazara göre, insanın kişiliğinin bir bütünlük kazanmasını, kimlik edinmesini sağlayan kapalı ve yapay bir mekân olarak ev ya da yurt, içerisini dolduran işaretleriyle birlikte, nasıl bir konumda ve durumda olursa olsun, aslî bir öz-yer niteliği taşıyor. İnsanyurt-hakikat bağlamında mantık temelli bir yaklaşım benimsemenin çok güvenilir bir tutum olmadığını ifade eden gezgin-yazar, evin ve yurdun ruh hâli olma özelliğini okuyucuya böylelikle hatırlatmış oluyor.

Sınırların içerisinde birer sembolik anlam kazanan işaretler, evin yapaysallığını algılanabilir bir somut resme dönüştürüyor. Gezgin-yazarın bir kapalı mekândan diğgerine geçerken çeşitli işaretler aracılığıyla gözlemlediği başkalık durumu, başka-yerde var olan evlerin ve yurtların, buralarda yaşayan insanların hayatı ve kimliği üzerinde nasıl kendine özel bir etki yarattığını, sınırlarla belirlenmiş bu kapalı mekânların böylelikle nasıl öz-yerlere dönüşebildiğini bize gösteriyor. Saint-Exupéry'nin önerdiği bakış açısından hareketle ifade etmek gerekirse, evin ve yurdun yapay kapalılığı, bu mekânları tanımlayan sınırların içinde yaşamını sürdüren insan için, bir hakikat, onun kişiliğinin önemli bir parçası olabilme potansiyeli taşıyor. Bu sınırların tanımladığı mekân, aynı zamanda o sınırlar içinde ikamet eden özne olarak insanı da bir şekilde tanımlıyor. Dolayısıyla, bir uzlaşısal mekân olarak, içinde ikamet eden öznenin kimliğini etkileyen ev ve yurt, uzlaşısal hayatın bir neticesi olan toplumsal kimliğin gerçekleşmesi açısından bir öz-yer rolü oynuyor. Bu nedenle, başka-yer deneyimi edinmek için evinden ayrılan gezgin-yazar için, başka yurtlar aynı zamanda başka kimlikler, başka hakikatler, başka insanlar anlamına geliyor.

Evin ve yurdun sınırlarının gerçeklikle ve mantıkla doğrudan bağlantılı olmadığı fikrini öne süren gezgin-yazar, bu düşüncesini, başka-yer deneyiminden hareketle bir zemine oturtuyor. Kendi evinin ve yurdunun sınırlarının yapay sınırlar olduğunu gören gezgin-yazar, bu sınırların belirli bir kapalılık ve bu kapalılığın sonucu olarak da belirli bir kimlik vücuda getirmek gerçeği ile doğrudan ilişkili olduğunu idrak ediyor ve bunu okuyucuya bu şekilde aktarıyor. Öte yandan, paradoksal bir biçimde, evin ve yurdun kapalılığı durumunun sonucu olarak, sınırı aşmak eylemi düşüncesi, gezgin-yazarda bir "başka-yerin çağrısı"13 motivasyonu ile paralel bir gelişme izliyor. Nitekim yapay olarak çizilmiş sınırın diğer tarafında, bilinmeyenin, alışılmamış olanın çekiciliği duruyor. Kendi yurdunun sınırının hemen ötesinde başka bir yaşam alanı uzandığını bilen ve bu başkayerde farklı bir kültürün, farklı bir yurdun, farklı bir alansal gerçekliğin olduğu fikri ile gezisini hayata geçiren gezgin-yazar, "sınırın ötesi"ne geçmeyi heyecan verici bir eylem olarak okuyucuya yansitiyor.

${ }_{13} \mathrm{Bu}$ terimi Frame'de "uzağın çağrısı" (186), Saint-Exupéry'de "yabani çağrı" (166), Kerouac'ta "yeryüzünün çağrısı" (227), Batur'da "yeniden Doğa'ya dönüş sancısı" (210), Kpomassie'de "bilinmeyenin çekiciliğgi" (266), Bouvier'de "ufuk değiştirme takıntısı" (94) şeklinde görüyoruz. 
Amerikalı gezgin-yazar Kerouac, başka-yer deneyimi sırasında iki yurdu ayıran, yani kendi yurdunu (Amerika) başka-yerden (Meksika) ayıran sınırı magic border ${ }^{14}$ olarak niteliyor ve bu isimlendirmeyle hem sınırın soyutluğuna gönderme yapmış oluyor, hem de böyle bir sınırın varlığının psikolojik boyutuna değinmiş oluyor. Nitekim bu sihirli sınırı aştı̆̆ını ancak çeşitli somut işaretlerle (sınır kapısı, giyim tarzı, dil, vs.) idrak edebilen gezgin-yazar, aynı zamanda başka-yere geçmiş olmanın onda yarattığı coşkuyu da dillendiriyor. Sınır fikri dolayısı ile alışılmış olanı geride bıraktığı, evinden farklı işaretlerle dolu bir yurda giriş yaptığı izlenimi edinen gezgin-yazar, başka-yer algısını, dolayısıyla da ev ve yurt algısını belirleyen mekânın yapay kapalılık durumunu gerçekdışı, aldatııı ancak bir o kadar da etkileyici ve heyecanlandırıcı bir durum olarak betimliyor.

Yapay bir alan olarak ev ve yurt, modern mekân algısının bir başka karakteristik yönünü teşkil ediyor. Doğal olmayan sınırlar aracılığıyla kendi içerisinde bir devamlılık sürdüren evler ve yurtlar, bu sınırlanmışlığın doğurduğu kendine özgülük ve başkalık ile gezgin-yazarın algısını farklı şekillerde etkiliyor. Kendi öz-yerini tanımlayan işaretler üzerine düşünen ve bu öz-yerin etrafı sınırlarla çizilmiş alanının aslında gerçek bir alan olmadığını idrak eden gezgin-yazar için başka-yer deneyimi, bu yapay gerçekliğe rağmen, bu durumun meydana getirdiği alansal farklılık ve çeşitlilik perspektifinde ilgi çekici bir eylem hâlini alıyor. Yani, yapay sınırlarla birbirlerinden ayrışmış evler ve yurtlar, gezginyazarın algısında, keşfedilmeyi bekleyen, bir "uzak çağrısı" yaratan yabancıl mekânlar formuna giriyor. Gezgin-yazar, sözünü ettiğimiz bu çağrıya cevap vermek adına, kendi evinin ve yurdunun yapay sınırlarını aşıp, başka-yerin alansal gerçekliğiyle karşı karşıya kalma yolunu seçiyor.

Başka-yerler keşfetmek, deneyimlemek amacı ile yola çıkan gezgin-yazar, alanı sınırlarla belirlenmiş yurtlar arasında geçişler yaparak, bu eylemi neticesinde edindiği izlenimler, kafasında oluşan soru işaretleri hakkında okuyucuyu bilgi sahibi kılıyor. Çağdaş gezi edebiyatı eserleri vasıtasıyla okuyucuya aktarılan bu bilgiler, sınırların belirleyici olduğu mekân gerçekliği ve onun doğurduğu mekân algısı ile ilintili olarak kimliğe ve kültüre dair yaklaşımlar ve tespitler içeriyor. Başka-yer tecrübesi neticesinde ev ve yurt tanımına farklı yorumlarla yaklaşan gezgin-yazar, bir yandan tanık olduğu mekânsal çeşitliliği heyecan verici bir olgu olarak tasvir ederken, diğer yandan bu yapaylığın gerçeklikle olan bağını gözden geçirmemizi sağlıyor.

\section{SONUÇ}

Sınır ve yabancı kavramları, Karşılaştırmalı Edebiyat sahasının anahtar kavramları arasında yer alıyor. Karşılaştırmalı Edebiyat disiplinini besleyen kaynaklardan biri olan çağdaş gezi edebiyatı, bünyesinde, bu kavramları yirminci ve yirmi birinci yüzyıla özgü bir perspektifle yeniden irdelemeye zemin hazırlayacak içerikte yapıtlar barındırıyor. Teknik ve teknolojik sahada kaydedilen ilerlemelerin bir sonucu olarak mekânlararası etkileşimin daha sık ve daha hızlı gerçekleştiği yirminci ve yirmi birinci yüzyıl, mekân kavramına dair bize çok yönlü, karmaşık, çoğul bir resim sunuyor.

Ev ve yurt kavramları, mekân algısı söz konusu olduğunda iki önemli algısal alanı işaret ediyor. Zira bu iki kavramın işaret ettiği mekân veya mekânlar, "diğer mekânlar"ın algılanışında belirleyici bir rol oynayabiliyor. Çağdaş gezi edebiyatında kendini ifade etme

14 Sihirli (veya büyülü) sinır.

SEFAD, 2018 (40): 1-22 
alanı bulan ve algılayıcı özne rolü ile mekânlar arası yer değiştiren gezgin-yazar, kendi evinin sınırlarından uzaklaşarak başka-yerin sınırlarının içerisine giriyor ve bu sınıraşırı deneyimi, hem ona hem de onun aracılığıyla okuyucuya, evin ve yurdun tek tanımdan ibaret olmadığını gösteriyor. Başka-yer deneyimi, gezgin-yazarın algısında ev ve yurt kavramlarına tekabül eden resim ya da resimleri değiştiriyor, onların tanımlarını çoğaltarak çizgilerini belirsizleştiriyor, sınırlarını yeniden çiziyor.

İnsanın hayatının sembolik, işlevsel ve merkezî mekânlarından olan ev/evler ya da yurt/yurtlar başka-yerlere, başka evlere yönelik algıyı etkileyen, kimliği, "öteki" yi, yabancıyı, ev/yurt dışında kalanı, uzak olanı kendine nazaran tanımlayabilme potansiyeline sahip özel mekânlar olma izlenimi veriyor. Öyle ki birtakım evler ve yurtlar, yarattıkları alansal etki ile gezgin-yazarın hayatında derin izler bırakabiliyor, bu kişi için birer öz-yere dönüşebiliyor. Kişinin mekân algısı bu öz-yere nazaran şekillenebiliyor.

Başka-yer ve öz-yer diyalektiğinde ev ve yurt, yirminci ve yirmi birinci yüzyıl edebiyatlarında, hissî, soyut ama aynı zamanda fizikî ve somut boyutları olan mekân/mekânlar olarak karşımıza çıkıyor. Öz-yerin hissîlik durumu, mahrem diyebileceğimiz kişisel bir nitelikte olup, başka-yer gerçekliği içinde kendine daha kalıcı ve daha belirgin bir yer bularak gezgin-yazarın zihninde, farklı şekillerde, beliriyor. Tamamen şahsî deneyiminin bir neticesi olarak gezgin-yazarın "benim yerim" diye nitelediği ev ve yurt, alışılmış formlardan öte, bazen sessiz, tenha ve tozlu bir yol da olabiliyor. Öz-yerin fizikî resmi ile yine başka-yerde karşılaşan gezgin-yazar, sakini olmadığı bu mekânları bir yabancı gözüyle algılıyor, tanığı olduğu bu diğer öz-yerler üzerine o an edindiği izlenimlerini okuyucu ile paylaşıyor. Böylece ev ve yurt; başka-yer ve öz-yer, geçmiş zaman ve şu an, algılayıcı özne ve algılanan obje ilişkileri bağlamında çok boyutlu tanımlara kavuşuyor, daha kapsayıcı bir imge hâlini alıyor.

Bu makale için seçilmiş ve içerisinde merkezî bir mekân olma niteliğiyle evin ve yurdun hissel, düşünsel, kavramsal nitelikte farklı boyutlarını göz önüne seren ögeler barındıran çağdaş gezi edebiyatı eserlerinin meydana getirdiği karmaşık birliktelik bize gösteriyor ki gezgin-yazarın algısında, ev, yurt, öz-yer, başka-yer değişken, göreceli, dinamik mekânlar olarak kendine yer buluyor. Öyle ki, ev olarak nitelenen bir mekân daha sonra başka-yere dönüşebiliyor. Aynı şekilde bir başka-yer, gezgin-yazarın algısında bir özyer resmine işaret edebiliyor. Ev aynı zamanda yurt olabilirken ya da bu iki kavram aynı özyer olma özelliği gösterebilirken, bu iki kavramın uyuşmadığı veya bunların bir öz-yer niteliği taşımadığı durumlar da ortaya çıkabiliyor. Nitekim başka-yer deneyimi ile doğru orantılı olarak, gezgin-yazar, mekânın dar tanımlara sığdırılamayacak kadar çok yönlü ve karmaşık bir unsur olduğunu anlıyor ve bunu okuyucusuna kelimeleri ile aktarıyor. Evin/yurdun açıklı̆̆g-kapalılığı, somut oluşu-soyut oluşu, kişisel karakteri-toplumsal karakteri, hissel oluşu-fiziksel oluşu ikilemleri mekân olgusunun karmaşıklığını ama aynı zamanda kapsayıcılığını gözler önüne seriyor. Bu karmaşıklık, mekân ile doğrudan ilişkili olan kimlik, kültür, kişilik gibi olguların da dar tanımlar kabul etmeyeceği fikrini bize veriyor.

Kişisel deneyiminin neticesi olarak mekân algısı genişleyen, değişen gezgin-yazar, eserinde yer verdiği edebî betimleme ve tanımlamalarla okuyucunun da dikkatini bu değişebilirliğe çekmek istiyor. Yabancı olanı, yabancı olanın gözüyle tanımış olan okuyucu, edebî düzlemde ve sıradanlıktan, alışılagelmiş olandan ayrışan, bilinmez ve heyecan veren bir olay örgüsü yansıtması dolayısıyla romanesk kabul edebileceğimiz bir üslup ile 
kendisine sunulan bu betimleme ve tanımlamalar aracılı̆̆ıyla, mekân kavramına, ev ve yurt kavramlarına, başka-yer ve öz-yer kavramlarına yaklaşımında farklı bakış açıları edinmiş oluyor.

Gezi edebiyatının kayda değer vasıflarından olan, belki de en önemli vasfı olan, "yabancı gözüyle mekân algısı" paradigması, kimlik, kişilik, kültür gibi insan-mekân ilişkisi eksenli ögeleri daha büyük ölçekli bir düzlemde irdelemeyi, ev ve yurt kavramlarına daha etraflıca bakabilmeyi mümkün hâle getiriyor. Her gezgin-yazarın deneyimi ve bu deneyimin edebî aktarımı, mekân algısının, başka-yer gerçekliğine nazaran, yeniden şekillenmesine, yeni bileşenler edinmesine katkıda bulunan birer kaynak, referans olma anlamı taşıyor. Bu yüzden her gezi edebiyatı eseri bu değişebilir, genişleyebilir tanımın eklenmeyi bekleyen potansiyel parçası olarak, okuyucunun keşfine hazır, aslî ama aynı zamanda tikel bir mekân resmi içeriyor.

Yirminci ve yirmi birinci yüzyıl gezi edebiyatında ev ve yurt algısını incelemeyi ve analiz etmeyi konu alan bu makale ile, olabildiğince birbirine uzak ülke edebiyatlarını temsil eden gezgin-yazarların hayata geçirmiş olduğu eserleri kaynak alarak, bu çeşitliliğin sonucu olarak birbirinden farklı, dikkate değer özellikler taşıyan sentetik bir mekân resmi sunuldu. Bu resim elbette eksiksiz, bitmiş bir resim değildir.

$\mathrm{Bu}$ makale ile ulaşılmak istenen, referans olarak alınan altı çağdaş gezi edebiyatı eserini birbirinden bağımsız bireysel deneyimleri aktaran otonom kaynaklar olarak kabul edip, bunların çizdiği çerçeve içerisinde kalmaya çalışarak ev ve yurt algısının birtakım ana hatlarını gün yüzüne çıkarmak ve bunlar üzerinden bir mekân analizi yapmak oldu. Sözünü ettiğimiz bu hedefe ulaşmanın yanı sıra, gezgin-yazarın kelimelerinden hareketle ortaya çıkan, mekânın düşünsel, fiziksel ve romanesk boyutlarını irdeleyen birtakım çağdaş yardımcı kaynak vasıtası ile de kavramsal çözümleme noktasında desteklenen bu betimsel ve tanımsal değerlendirme çalışması, birbirini tamamlayan ya da besleyen özellikler üzerinden bütün gibi görünmekle beraber, gezgin-yazarların bireysel deneyimlerinden kaynaklandığı ve gezi edebiyatını temsil eden başka eserlerin sunduğu mekân tanımlamalarını ve betimlemeleri içine almaması dolayısıyla eksik bir resim özelliği de göstermektedir.

Farklı edebiyatlara ait seçilmiş altı eserin sunduğu ögeler esas alınmak suretiyle bireysel mekân deneyiminin, bu deneyimi aktarmada etken olan dil, kültürel kimlik, kişilik, kişiliğin bedensel ve hissel bileşenleri gibi faktörler nedeniyle sebep olduğu ve beslediği bütünlük ve kısmîlik paradoksu dikkate alınılarak, mekân algısının farklılığını, çeşitliliğini ve tek gerçekliğe indirgenemezliğini göstermeye çalışan bu makale ile ulaşılan noktadan hareketle, aynı zamanda, gezi edebiyatı eserlerini incelemede kaynak teşkil edebilecek bir gezi edebiyatı teorisi geliştirmeye dönük nitelikte, bu alan üzerine gerçekleştirilecek çalışmalara dair bir perspektif de sunulmuştur.

\section{SUMMARY}

In relation with technical and technological progress that have made the communication between places faster and more frequent, the conception of home represents a significant issue in twentieth and twenty-first centuries. Home, a conceptual notion designating a central place for human living, refers to a symbolic place which is also related to terms like identity, culture, personality. The notion of home embodies particular conditions regarding the relation between human being as perceiver subject and place as 
perceived object. By choosing New Criticism as the method to approach the contemporary literary works selected for the development of this work after their potential quality to be part of a "travel literature theory", this paper aims to constitute a definition of place from the perspective of literary travelers who carry out considerations about the signification of place from their own personal experiences that are taken place in elsewhere, in other-place, in places situated far from home, far from the ordinary, the familiar, the known. This is because New Criticism takes every single literary work as an autonomous integrity. Travel literature works selected for the realization of this article are analyzed to give form to a referential hypothesis about conception of home, by staying in the frame which is delineated by the content of each single book.

Contemporary literary creations, representing traveler-writers from far and various geographies and situations, are susceptible to imply integral narratives reporting personal experiences achieved in dissimilar places and in a certain period of time. Likewise, each travel experience acquired, achieved and reported by traveler-writer designates a whole concept of place which can be also considered as a singular piece of global concept of place. The traveler-writer, as a perceiver subject, transmits, through her/his individual witness effected in other-place, a definition of place which becomes, for reader, a referential statement on spatial reality. On the other hand, compared to another traveler-writer who represents another perceiver subject experimenting the place as a perceived object, every personal experience is, in the end, equivalent of a partial reality regarding the conception of place. Thus, by this article, that wholeness and partialness are supposed to define altogether the outlook that is proposed by this work. In fact, the main resolution of this paper is underlining those two significant and revealing conditions when it comes to notice the conception of place, more particularly of home, in accordance with human condition.

Six traveler-writers who are consulted in this article to understand the notion of home and the condition of place because of their role as perceiver subjects, have different cultural identities and personalities reflecting yet the complexity of relation between human being and place. This complexity is essential to reveal diverse aspects of home which appears in plural forms due to its compounded signification. Given such state of diversity, this work envisages to present multiple aspects related to this complex representation of place by demonstrating different points of view in reference to notion of home. Therefore, realized in situations and conditions being independent from each other, the experiences of travelerwriters, through their complementary or supporting quality which is reported inside literary works in forms of definitions and approaches, will help to reveal several aspects of conception of home, a sort of conception that reflects a particular spatial reality which is in an irreducibly changing relation with human living. In this respect, the result of this work will show that all kind of judgement about a definition of home is at the same time adequate and inadequate due to complexity of conception of place.

In this article, French words ailleurs (elsewhere, another place, other-place), distance (distance) and chez-soi (self-place, own-place) are used, through their possible correspondences in Turkish language (respectively: başka-yer, mesafe, öz-yer), as references to describe, in the most possibly accurate and exhaustive way, spatial situations and conditions so as to make more extensive and correlate the comprehension of the word "home". So, the words of traveler-writers, conceived for the elaboration of the question of conception of place, are the main components that are set to develop and conclude the subject of this 
present work which will offer, in a Comparative Literature context, a certain perspective in terms of studies for a theory of travel literature. At that stage, six traveler-writers representing six different countries (New Zealand, Turkey, United States of America, Togo, Switzerland, France) are expected to contribute to form the conceptual image related to notion of home, to highlight the term of place in the context of strangeness and strangerness, both being pivotal words for the discipline of Comparative Literature. Besides the main reference works selected as essential sources for the elaboration of the subject of this article, a few number of collateral works, related to the argument of this paper, will be also consulted exclusively for a conceptual analysis.

To develop the subject of this work in a more organized way, four chapters have been constituted between introduction and conclusion parts. Those chapters are: "Home as a State of Mind", "Home as a Changing Entity", "Home as a Closed Space" and "Home as an Artificial Place". It is useful to be reminded that in every chapter, the conception of home is considered under a different conceptual aspect and through a variety of approaches suggested in selected works. By including such a range of various aspects (concrete, abstract, symbolic, physical, psychological, sensible, nostalgic, actual, individual, relative, conventional), the intention will be reflecting, in a more noticeable manner, the complexity of notion of home. That is to say, as the result will expose it clearly, this complex and diverging reflection will nevertheless need other approaches as well as other descriptive and defining elements in terms of a more complete image when it comes to conceptualize home as an object perceived by traveler-writer as a perceiver subject.

For this article, are chosen six literary works written in three languages (French, Turkish or English) and published in different periods of twentieth and twenty-first centuries. Those works, belonging to six literatures from five continents, relate individual travel experiences realized in countries and continents different from each other, have been created by writers who represent a diversity of cultural identities. Readers can find in those works conceptual, intellectual, individual and romanesque approaches related to question of place. According to their first publication dates, those works are: Terre des hommes, Antoine de Saint-Exupéry (France, 1939); On the road, Jack Kerouac (United States of America, 1957); L'Africain du Groenland, Tété-Michel Kpomassie (Togo, 1981); Le poisson-scorpion, Nicolas Bouvier (Switzerland, 1982); Başka Yollar, Enis Batur (Turkey, 2002); Towards Another Summer, Janet Frame (New Zealand, 2007 *Post-mortem publication).

SEFAD, 2018 (40): 1-22 


\section{KAYNAKÇA}

Bachelard, Gaston (1967). La poétique de l'espace. Vendôme: Presses Universitaires de France.

Batur, Enis (2013). Başka Yollar. İstanbul: Kırmızı Kedi.

Bouvier, Nicolas (2011). Le poisson-scorpion. Barselona: Gallimard.

Chevrel, Yves (2016). La Littérature Comparée. Clamecy: Presses Universitaires de France.

CNRTL (Fransa Ulusal Metin ve Sözlük Veritabanı) Sözlüğü. "Ailleurs". http://www.cnrtl.fr/definition/ailleurs [10.07.2018].

CNRTL (Fransa Ulusal Metin ve Sözlük Veritabanı) Sözlüğü. "Chez-Soi". http://www.cnrtl.fr/definition/chez-soi [10.07.2018]

Das, Bijay Kumar (2005). Twentieth Century Literary Criticism. Delhi: Atlantic.

Dictionnaire de la Langue Française par E. Littré de l'Académie Française (1873). Paris: Hachette.

Dictionnaire Latin-Français par Fr. Noel (1825). Paris: Le Normant Père.

Ducros, Paul (2011). Husserl et le géostatisme. Paris: Cerf.

Esquier, Francis (2000). "Habiter: le lieu et son atmosphère". Revue de Métaphysique et de Morale.

Frame, Janet (2007). Towards Another Summer. Auckland: Vintage.

Imamoglu, Abdulfettah (2017). La notion d "Ailleurs" dans les récits romanesques du XXE et $d u$ XXIE siècles. Doktora Tezi. Lyon: Ecole Normale Supérieure de Lyon.

Kerouac, Jack (2000). On the road. St Ives: Penguin Books.

Kpomassie, Tété-Michel (1981). L'Africain du Groenland. Paris: Flammarion.

Perec, Georges (2000). Espèces d'espaces. Paris: Galilée.

Saint-Exupéry, Antoine de (2007). Terre des hommes. Hong Kong: Gallimard. 